\title{
Effects of Different Oxyanions on Arsenic Uptake by Rice Plants
}

\author{
Minsura Begum ${ }^{\text {** }}$ and S. Mondal ${ }^{2}$ \\ Department of Plant Physiology, Bidhan Chandra Krishi Viswavidyalaya, \\ Mohanpur, Nadia-741252, West Bengal, India \\ *Corresponding author
}

\section{A B S T R A C T}

\begin{tabular}{|l|l|l|l|l}
\hline Keywords & $\begin{array}{l}\text { Elevated arsenic content in food crops pose a serious human health risk. Rice is } \\
\text { the main food crop is possibly cultivated on contaminated sites. A study was } \\
\text { conducted to study effects of different oxyanions on arsenic uptake by rice plants. } \\
\text { Arsenic, Nitrate, } \\
\text { sulphate, Rice }\end{array}$ & $\begin{array}{l}\text { Shoot arsenic concentrations under phosphate treatments were comparatively } \\
\text { lower than under the corresponding concentration of nitrate and sulphate } \\
\text { treatments in arsenic contaminated condition. Root arsenic concentration } \\
\text { decreased with increase in concentration of nitrate and phosphate in the nutrient } \\
\text { Article Info }\end{array}$ \\
$\begin{array}{l}\text { Accepted: } \\
\text { 12 December 2018 } \\
\text { Available Online: } \\
\text { 10 January 2019 }\end{array}$ & $\begin{array}{l}\text { shoot by promoting tissue growth it appeared to have little effect on uptake and } \\
\text { translocation. }\end{array}$ \\
\hline \hline
\end{tabular}

\section{Introduction}

Arsenic (As) is an important environmental contaminant in many regions. Especially inorganic As species like arsenite and arsenate are highly carcinogenic posing a possible health risk to humans. Arsenic enters the human food chain mainly via drinking water or via food crops.

Among these rice has been attributed a main source of as intake especially for populations with rice-based diet. Therefore rice has been the target cereal for investigating uptake and accumulation mechanisms in recent years $(\mathrm{Li}$ and Lombi, 2009). Arsenic is non-nutrient element and the dominant inorganic species of arsenic namely arsenate and arsenite are oxyanions of arsenic.

Essential nutrient element like nitrogen and phosphorus have similarity in their atomic structure, all have five electron in outer orbit and group $\mathrm{V}$ element. Nitrogen, phosphorus and arsenic belong to the periods 2, 3, and 4 respectively. Sulphur is a group VI element of period 3.

All these nutrient elements are taken up by plants as their oxy-anions, nitrogen as nitrate, phosphorus as phosphate and sulphur as sulphate. Effects of different oxyanions on arsenic uptake by rice plants is of course a worth study. 


\section{Materials and Methods}

This experiment was conducted in net house under the Directorate of Research, Bidhan Chandra Krishi Viswavidyalaya, Kalyani, Nadia. Rasi (IET-1444), a popular rice genotype and $\mathrm{TN}-1$ female parent of Rasi were selected and grown hydroponically.

Rice seeds (Oryza sativa $\mathrm{L}$ ) cv. Rasi and $\mathrm{TN}-1$ were surface sterilized with $0.1 \%(\mathrm{w} / \mathrm{v}) \mathrm{HgCl}_{2}$ for two minutes, washed repeatedly with glass distilled water, seeds were grown in pots for 35 days and after 35 days plants were transferred in Hoagland's solution. Seedlings with uniform growth and vigor were taken for experiment. The roots of such seedlings were properly washed initially with the tap water to remove the soil and other materials and finally with distilled water before transferring them in the culture solution.

\section{Procedure of planting}

The roots of the seedlings were carefully inserted through the hole of the lid made up of thermocole and set on the top of the bucket. Staking was done to keep the seedling standing straight so that root part of the plant could reach the nutrient solution of the bucket. Every care was taken to avoid any physical damage of the seedling either at the root zones or in the aerial portion.

\section{Preparation of culture solution}

Basic culture solution was prepared by adding appropriate concentration of nutrients in Hoagland's solution $\left(\begin{array}{llll}250 & \mathrm{ml}\end{array}\right)(\mathrm{pH} \quad 5.5)$ containing (in $\mathrm{mM}$ ): $\mathrm{KNO}_{3}: 20$; $\mathrm{Ca}\left(\mathrm{NO}_{3}\right)_{2}$, 2.0; $\mathrm{MgSO}_{4}, 0.7$; and (in $\mu \mathrm{M}$ ), Fe-EDTA, $0.50 ; \mathrm{ZnSO}_{4}, 0.5 ; \mathrm{CuSO}_{4}, 0.5 ; \mathrm{MnSO}_{4}, 2.5$; $\mathrm{H}_{3} \mathrm{BO}_{3}, 5 ;, \mathrm{Na}_{2} \mathrm{MO}_{4}, 0.25 ; \mathrm{CuSO}_{4}, 0.09$. In which arsenite in the form of Sodium arsenite $\left(\mathrm{NaAsO}_{2}, \mathrm{M} . \mathrm{W} .=129.91\right)$ were used and plants were treated with arsenite $(10 \mathrm{mg} / \mathrm{l})$ in which three levels of nutrient oxyanions in the form of $\mathrm{MgSO}_{4}, \mathrm{KNO}_{3}, \mathrm{KH}_{2} \mathrm{PO}_{4}(0.5 \mathrm{mM}, 1.0 \mathrm{mM}$, $2.0 \mathrm{mM}$ ) were used. After 3 days plants were removed from hydroponics and placed in drier for arsenic analysis.

\section{Analysis of the total arsenic in plant sample}

\section{Preparation and digestion of plant sample}

After 3 days of treatment, leaves and root from the rice seedling sample were digested in an Erlenmeyer flask by a mixture of concentrated tri-acids, e.g., $\mathrm{HNO}_{3}, \mathrm{HClO}_{4}$ and $\mathrm{H}_{2} \mathrm{SO}_{4}$ in a proportion of 10:4:1 (v/v) (Sparks et al., 2006). After an overnight reaction, the content of the flask were gently boiled on an electric heater for digestion. The entire digestion process lasted 3-4 h. after complete digestion, the solution was diluted with double distilled water and filtered by Whatman No. 42 filter paper and transferred in to acidwashed plastic bottle; this solution was used for analyzing the arsenic and phosphorus content of the sample. Each treatment was performed in triplicate. The digest was diluted to $20 \mathrm{ml}$.

\section{Determination of 'As' in plant sample}

Two $\mathrm{ml}$ of the aliquot was taken in $10 \mathrm{ml}$ plastic tube, $1 \mathrm{ml}$ of concentrated $\mathrm{HCl}$ and 1 $\mathrm{ml}$ of mixed reagent [5\% KI (w/v) $+5 \%$ Ascorbic acid (w/v)] were added to it, kept for 45 minutes to ensure complete reaction and the volume was made up to $10 \mathrm{ml}$ The resultant solution was analyzed in a PerkinElmer Atomic Absorption Spectrophotometer with Flow Injection Analysis System (FIAS 400) @ $1_{\max } @ 193.7 \mathrm{~nm}$ where the carrier solution was $10 \% \mathrm{v} / \mathrm{v} \mathrm{HCl}$, the reducing agent (to ensure all As species be reduced to $\mathrm{AsH}_{3}$ and to be measured against a calibration with standard $\mathrm{As}^{+3}$ solution) was $0.2 \% \mathrm{NaBH}_{4}$ in $0.05 \% \mathrm{NaOH}$ (Schmidt et al., 2004). 


\section{Statistical analysis}

The data of different parameters collected, were subjected to statistical analysis as per design(s) following the method described by Panse and Sukhatme (1989) to find out the significance between treatments used in the experiment. The experimental data for the characters were subjected to the variance analysis appropriate to a CRD design.

\section{Results and Discussion}

Shoot arsenic concentration $(\mathrm{mg} / \mathrm{kg})$ under different concentration of oxy-anion with As-III

The variations in shoot arsenic concentration under As-III contaminated nutrient medium due to genotypes, treatment and genotype treatment interaction were statistically significant. Such result indicates that uptake varies with the genotypes, species and concentration of oxy-anion and also with interaction between genotype and treatment. Average shoot As concentration of Rasi was higher than $\mathrm{TN}-1$.

Shoot As concentrations under contaminated treatments in combination with nutrient oxyanions were lower than that under only As-III treatment. It was comparatively lower under phosphate treatment then the other two oxyanion treatments. Shoot arsenic concentrations under phosphate treatments were comparatively lower than that under the corresponding concentration of nitrate and sulphate treatments.

Shoot As concentrations were found to decrease with increase in concentration of each of the nutrient oxy-anions. The trend in shoot arsenic concentration of TN-1 was also similar to Rasi with only difference that it was lower than Rasi under every corresponding treatment (Table 1).

Table.1 Shoot concentration $(\mathrm{mg} / \mathrm{kg})$ under different concentration of oxy- anion with As-III

\begin{tabular}{|c|c|c|c|}
\hline \multirow[t]{2}{*}{ Treatments } & \multicolumn{2}{|c|}{ Genotypes } & \multirow[t]{2}{*}{ Mean } \\
\hline & Rasi & TN-1 & \\
\hline Control (Distilled water) & 0.970 & 0.507 & 0.739 \\
\hline as(iii) 10 ppm & 12.353 & 9.630 & 10.992 \\
\hline $\mathrm{AS}(\mathrm{III}) 10 \mathrm{mg} / \mathrm{l}+\mathrm{MgSO}_{4} 0.5 \mathrm{mM}$ & 11.550 & 8.560 & 10.055 \\
\hline $\mathrm{AS}(\mathrm{III}) 10 \mathrm{mg} / \mathrm{l}+\mathrm{MgSO}_{4} 1.0 \mathrm{mM}$ & 11.497 & 5.400 & 8.449 \\
\hline $\mathrm{AS}(\mathrm{III}) 10 \mathrm{mg} / \mathrm{l}+\mathrm{MgSO}_{4} 2.0 \mathrm{mM}$ & 10.280 & 3.637 & 6.959 \\
\hline $\mathrm{AS}(\mathrm{III}) 10 \mathrm{mg} / \mathrm{l}+\mathrm{KNO}_{3} 0.5 \mathrm{mM}$ & 10.690 & 8.310 & 9.500 \\
\hline $\mathrm{AS}(\mathrm{III}) 10 \mathrm{mg} / \mathrm{l}+\mathrm{KNO}_{3} 1.0 \mathrm{mM}$ & 8.653 & 6.660 & 7.657 \\
\hline $\mathrm{AS}(\mathrm{III}) 10 \mathrm{mg} / \mathrm{l}+\mathrm{KNO}_{3} 2.0 \mathrm{mM}$ & 7.470 & 6.590 & 7.030 \\
\hline $\mathrm{AS}$ (III) $10 \mathrm{mg} / \mathrm{l}+\mathrm{KH}_{2} \mathrm{PO}_{4} 0.5 \mathrm{mM}$ & 9.123 & 6.317 & 7.720 \\
\hline $\mathrm{AS}$ (III) $10 \mathrm{mg} / \mathrm{l}+\mathrm{KH}_{2} \mathrm{PO}_{4} 1.0 \mathrm{mM}$ & 7.033 & 6.050 & 6.542 \\
\hline $\mathrm{AS}(\mathrm{III}) 10 \mathrm{mg} / \mathrm{l}+\mathrm{KH}_{2} \mathrm{PO}_{4} 2.0 \mathrm{mM}$ & 6.420 & 5.303 & 5.862 \\
\hline Mean & 8.731 & 6.088 & 7.409 \\
\hline For comparison mean of & $\operatorname{SEm}( \pm)$ & & $0.05)$ \\
\hline $\mathbf{V}$ & 0.0568 & & \\
\hline $\mathbf{T}$ & 0.1332 & & \\
\hline $\mathbf{V} \times \mathbf{T}$ & 0.1884 & & \\
\hline
\end{tabular}


Table.2 Root arsenic concentration $(\mathrm{mg} / \mathrm{kg})$ under different concentration of oxyanion with As-III

\begin{tabular}{|c|c|c|c|}
\hline \multirow[t]{2}{*}{ Treatments } & \multicolumn{2}{|c|}{ Genotypes } & \multirow[t]{2}{*}{ Mean } \\
\hline & Rasi & TN-1 & \\
\hline Control (Distilled water) & 11.493 & 5.873 & 8.683 \\
\hline AS(III) 10 ppm & 79.023 & 63.380 & 71.201 \\
\hline $\mathrm{AS}(\mathrm{III}) 10 \mathrm{mg} / \mathrm{l}+\mathrm{MgSO}_{4} 0.5 \mathrm{mM}$ & 81.110 & 64.227 & 72.668 \\
\hline $\mathrm{AS}(\mathrm{III}) 10 \mathrm{mg} / \mathrm{l}+\mathrm{MgSO}_{4} 1.0 \mathrm{mM}$ & 83.830 & 65.647 & 74.7383 \\
\hline $\mathrm{AS}(\mathrm{III}) 10 \mathrm{mg} / \mathrm{l}+\mathrm{MgSO}_{4} 2.0 \mathrm{mM}$ & 84.460 & 67.867 & 76.163 \\
\hline $\mathrm{AS}(\mathrm{III}) 10 \mathrm{mg} / \mathrm{l}+\mathrm{KNO}_{3} 0.5 \mathrm{mM}$ & 78.760 & 62.907 & 70.833 \\
\hline $\mathrm{AS}(\mathrm{III}) 10 \mathrm{mg} / \mathrm{l}+\mathrm{KNO}_{3} 1.0 \mathrm{mM}$ & 77.750 & 62.613 & 70.181 \\
\hline $\mathrm{AS}(\mathrm{III}) 10 \mathrm{mg} / \mathrm{l}+\mathrm{KNO}_{3} 2.0 \mathrm{mM}$ & 75.783 & 58.437 & 67.110 \\
\hline $\mathrm{AS}(\mathrm{III}) 10 \mathrm{mg} / \mathrm{l}+\mathrm{KH}_{2} \mathrm{PO}_{4} 0.5 \mathrm{mM}$ & 72.7800 & 54.823 & 63.802 \\
\hline $\mathrm{AS}$ (III) $10 \mathrm{mg} / \mathrm{l}+\mathrm{KH}_{2} \mathrm{PO}_{4} 1.0 \mathrm{mM}$ & 63.837 & 50.500 & 57.168 \\
\hline $\mathrm{AS}(\mathrm{III}) 10 \mathrm{mg} / \mathrm{l}+\mathrm{KH}_{2} \mathrm{PO}_{4} 2.0 \mathrm{mM}$ & 61.953 & 41.183 & 51.568 \\
\hline Mean & 70.071 & 54.314 & 62.193 \\
\hline For comparison mean of & $\operatorname{SEm}( \pm)$ & \multicolumn{2}{|c|}{$\mathrm{CD}(\mathrm{P}=\mathbf{0 . 0 5})$} \\
\hline $\mathbf{V}$ & 0.3264 & \multicolumn{2}{|c|}{0.9302} \\
\hline $\mathbf{T}$ & 0.7655 & \multicolumn{2}{|c|}{2.1816} \\
\hline $\mathbf{V} \times \mathbf{T}$ & 1.0826 & \multicolumn{2}{|c|}{3.0853} \\
\hline
\end{tabular}

Root Arsenic concentration (mg/kg) under different concentration of oxy-anion with As-III

The variations in root As concentration due to genotypes, treatment (nutrient oxy-anions of different concentration) and genotype treatment interaction were statistically significant. Such result indicates that uptake varies with the genotypes, species and concentration of oxy-anions and also with interaction between genotype and treatment.

Average root As concentration of Rasi was higher than $\mathrm{TN}-1$. Root As concentrations under As-III contaminated treatments in combination with nutrient oxy-anions except sulphate were lower than that under only AsIII treatment. But it was higher than that under only As -III treatment in cases of sulphate treatments. Average root As concentration of Rasi under AsIII was lowest in cases of nitrate treatments. In Rasi root arsenic concentration decreased with increase in concentration of nitrate and phosphate in the nutrient medium whereas increased with increase in sulphate concentration in the nutrient medium. But in $\mathrm{TN}-1$ change in concentration of the oxy-anion in the nutrient medium caused no significant difference in root arsenic concentration (Table 2).

Reduction in tissue arsenic concentration at higher level of phosphorous in the growing medium was also reported by Wang and Duan (2009). Arsenate was reported to compete directly with phosphate at uptake level (Tu and Ma, 2003; Wang et al., 2002). Hence, high level of phosphorous in the growing media caused decline in tissue concentration of arsenic. Decline in translocation of arsenic under higher level of Sulfur is in agreement with the report made by Zhang et al., (2010) who claimed that sulfur deprivation caused 
enhanced translocation of arsenic from root to shoot.

In conclusion, shoot arsenic concentrations under phosphate treatments were comparatively lower than under the corresponding concentration of nitrate and sulphate treatments in As-III contaminated condition. Root arsenic concentration decreased with increase in concentration of nitrate and phosphate in the nutrient medium whereas increased with increase in sulphate concentration in the nutrient medium in As-III contaminated condition. Increased sulphate level caused little decline in shoot uptake but caused relatively greater decline in translocation. Increased level of nitrate though diluted arsenic concentration in root and shoot by promoting tissue growth it appeared to have little effect on uptake and translocation.

\section{References}

Li, R. Y. and Lombi, E (2009). Speciation and distribution of arsenic and localization of nutrients in rice grains. New Phytol. 184, 193-201.

Panse, D. G. and Sukhatme, P. V. (1989). Statistical methods for agricultural workers. ICAR, New Delhi.

Schmidt, D., F, Pitten, Muller, D. (2004). Risk assessment of a form military base contaminated with organoarsenic-based warfare agents: Uptake of arsenic by terrestrial plants. Science of the total Environ. 226, 237-245.

Tu, C., Ma, L. Q., (2003). Effects of arsenate and phosphate on their accumulation by an arsenic- hyperaccumulator Pteris vittata L. Plant Soil 249, 373-382.

Wang, J. R., Zhao, F. J., Meharg, A. A., Raab, A., Feldman, J. and McGrath, S. P. (2002). Mechanisms of arsenic hyperaccumulation in Pteris vittata. Uptake kinetics, interactions with phosphate, and arsenic speciation. Plant Physiol., 130: 1552.

Wang, L. and Duan G, (2009). Effect of external and internal phosphate status on arsenic toxicity and accumulation in rice seedlings. Journal of Environmental Sci., 21: 346-351.

Zhang, F. J., McGrath, S. P. and Meharg, A. A., (2010) Arsenic as a food chain contaminant: mechanisms of plant uptake and metabolism and mitigation strategies. Annu. Rev. Plant Biol. 61, 535-559.

\section{How to cite this article:}

Minsura Begum and Mondal, S. 2019. Effects of Different Oxyanions on Arsenic Uptake by Rice Plants. Int.J.Curr.Microbiol.App.Sci. 8(01): 1431-1435.

doi: https://doi.org/10.20546/ijcmas.2019.801.152 